\title{
The shifting landscape of African-Pentecostalism in Kenya
}

\begin{tabular}{|c|c|}
\hline $\begin{array}{l}\text { Author: } \\
\text { Julius M. Gath }\end{array}$ & $\operatorname{ogo}^{1,2,3}$ \\
\hline $\begin{array}{l}\text { Affiliations: } \\
{ }^{1} \text { Department } \\
\text { Spirituality, Ch } \\
\text { and Missiolog } \\
\text { Humanities, U } \\
\text { South Africa, } \\
\text { South Africa }\end{array}$ & $\begin{array}{l}\text { f Christian } \\
\text { urch History } \\
\text {, Faculty of } \\
\text { niversity of } \\
\text { retoria, }\end{array}$ \\
\hline $\begin{array}{l}{ }^{2} \text { Department } \\
\text { and Religious } \\
\text { of Humanities } \\
\text { University, Mc }\end{array}$ & $\begin{array}{l}\text { f Philosophy } \\
\text { Ktudies, Faculty } \\
\text { Kenyatta } \\
\text { mbasa, Kenya }\end{array}$ \\
\hline $\begin{array}{l}{ }^{3} \text { Department } \\
\text { Faculty of The } \\
\text { Amarillo, TX, } L \\
\text { America }\end{array}$ & $\begin{array}{l}\text { f Theology, } \\
\text { ology, ANCCI, } \\
\text { Inited States of }\end{array}$ \\
\hline $\begin{array}{l}\text { Correspondin } \\
\text { Julius Gathog } \\
\text { jumgathogo@ }\end{array}$ & $\begin{array}{l}\text { gauthor: } \\
\text { gmail.com }\end{array}$ \\
\hline $\begin{array}{l}\text { Dates: } \\
\text { Received: } 06 \text { I } \\
\text { Accepted: } 23 \\
\text { Published: } 13\end{array}$ & $\begin{array}{l}\text { May } 2021 \\
\text { une } 2021 \\
\text { Jan. } 2022\end{array}$ \\
\hline $\begin{array}{l}\text { How to cite th } \\
\text { Gathogo, J.M. } \\
\text { shifting landsc } \\
\text { African-Pente } \\
\text { Kenya', Theolo } \\
46(1) \text {, a121. h } \\
\text { org/10.4102/t }\end{array}$ & $\begin{array}{l}\text { is article: } \\
2022, \text { 'The } \\
\text { ape of } \\
\text { ostalism in } \\
\text { gia Viatorum } \\
\text { tps://doi. } \\
\text { v.v46i1.121 }\end{array}$ \\
\hline $\begin{array}{l}\text { Copyright: } \\
\text { (c) 2022. The } A \\
\text { Licensee: AOS } \\
\text { is licensed und } \\
\text { Creative Comr } \\
\text { Attribution Lic }\end{array}$ & $\begin{array}{l}\text { uthors. } \\
\text { S. This work } \\
\text { ler the } \\
\text { nons } \\
\text { ense. }\end{array}$ \\
\hline Read online: & \\
\hline 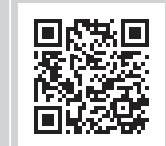 & $\begin{array}{l}\text { Scan this QR } \\
\text { code with your } \\
\text { smart phone or } \\
\text { mobile device } \\
\text { to read online. }\end{array}$ \\
\hline
\end{tabular}

Author:

Affiliations:

${ }^{1}$ Department of Christian and Missiolo Humanities, University of South Africa, Pretoria

South Africa nd Religious Studies, Faculty of Humanities, Kenyatta

${ }^{3}$ Department of Theology, Faculty of Theology, ANCCI, Amarillo, TX, United States of Corresponding author: Julius Gathogo,

Dates:

Accepted: 23 June 2021

How to cite this article: Gathogo, J.M., 2022, 'The shifting landscape of African-Pentecostalism in 46(1), a121. https://doi. org/10.4102/tv.v46i1.121

Licensee: AOSIS. This work

is licensed under the

Creative Commons

Attribution License.
I define African Pentecostalism as the Pentecostal thread that embraces some elements of African culture, without necessarily admitting it. It embraces some elements of the African heritage consciously or unconsciously. This research article sets on the premise that African Pentecostalism is the ideal phrase when referring to Pentecostalism in Africa. This drives us to consider the uniqueness of Pentecostalism in Africa rather than generalising its presence. This article seeks to demonstrate that African Pentecostalism in the 21st-century Kenya has undergone paradigm shifts in various dimensions, which includes leadership structuring, political orientations, modes of disciplining, eschatological concern, structural make-up, economic domain, health concern, ecumenical relations, gender relations, identity politics, theological education, poverty concern, use of science and technology, and general practices. Has the religious outfits that referred the earthly concerns as temporal tents and largely focused on the 'eternal house in heaven, not built by human hands' (2 Cor 5:1) appreciated the necessity of God's kingdom and will-being 'done on earth, as it is in heaven' (Mt 6:10)? In light of the coronavirus disease-2019 (COVID-19), has the ecclesiastical model that was too conservative become liberal in nature? The methodology includes interviews with selected people who are connected to this topic, participant observation and through an extensive review of the relevant literature.

Keywords: African Pentecostalism; from ministries to church; shifting landscapes; African heritage; COVID-19; Full Gospel Churches of Kenya.

\section{Introduction}

African Pentecostalism describes a variety of Christian communities who attribute their daily religio-social experiences with the workings of the Holy Spirit, and this is in keeping with the socio-cultural and the historical contexts of Africa. African-Pentecostal Churches in Kenya will include but not limited to 'Mombasa Pentecostal Churches (MPC), Deliverance Church of Kenya (DCK), Jesus Is Alive Ministries (JIAM-Nairobi), Jesus Celebration Centre (JCC-Mombasa), Neno Evangelism Ministries, The Happy Churches, Faith Evangelistic Ministries, Jubilee Christian Centre (JCC-Nairobi), Christ is the Answer Ministries (CITAMNairobi), and the Winners Chapel International Ministries, among others' (Gathogo 2011a:134; Gathogo 2014:1499-1515). As implied in Kalu (2008:186), African Pentecostalism produces a continuity by mining the ancient worldview and 'reproducing an identifiable character, and regaining a pneumatic and charismatic religiosity that existed in traditional society'. Kalu's (2008) position echoed Samuel Kibicho's (2006) concept of radical continuity, a phenomenon where he demonstrates that there is a Radical Continuity in the African indigenous systems even when it interacts with the Christian faith. As noted in Gathogo (2017), this radical continuity is manifested in the lives of Africans who convert to Christianity. Such African converts to Christianity find themselves necessarily practising some of the rituals that are also practised in the African indigenous heritage. Kaunda and John (2020:1) have expressed the view that whatever African Pentecostalism is, in essence, substance, function and even in its pneumatological expressions, it 'is largely informed by African religio-cultural innovations'. Their views are in continuum with those of Wariboko (2017) who avers that African Pentecostalism:

Is an assemblage of practices, ideas, and theologies - and interpretations of reality - whose tangled roots burrow deep into the three segments of African temporality... the 'spirit' of African Pentecostalism does not signify a distilled essence, changeless core, irreducible substrate, or perfection of being but is deployed for the sake of highlighting specific observations, contemplations, and questions that point to something of broader significance for understanding the multidirectional 
openness of African Pentecostal social life without presuming a constrictive universalizing framework. (p. 1)

Wariboko's (2017:1) classical description of African Pentecostalism shows its multidimensional and multidirectional nature, and indeed, its broad dimension that captures diverse expressions. As a term, African Pentecostalism best describes the uniquely African dimension of Pentecostalism that captures the African ethos of wholeness without necessarily appearing to duplicate Euro-American Pentecostalism in the African continent.

\section{Pentecostalism in Kenya}

As we shall see, Pentecostalism, or a semblance of it has been in Kenya since 1895 and 1912, and indeed, an AfricanPentecostal movement (a phenomenon where indigenous input is visible) has been in Kenya since the 1960s. In other words, it is in 1960 when:

\begin{abstract}
... the renowned international American evangelist Billy Graham visited Kenya and in effect began Pentecostalism in Kenya [despite being a member of the Baptist Church]. He was closely followed by another renowned evangelist; T.L. Osborn whose series of crusades gave impetus for open air preaching. David Barrett has noted that an earlier crusade by Osborn in 1957 at Mombasa led to a widespread Pentecostal movement. A visit, in 1968, by another Pentecostal preacher, Oral Roberts, and his subsequent healing rallies in Nairobi marked a major turning point in the history and establishment of Pentecostal churches. (Gathogo 2020a:394)
\end{abstract}

In particular, William Franklin Graham Jr. (1918-2018), popularly called Billy Graham, an American evangelist, a prominent evangelical Christian figure and an ordained Southern Baptist minister who became well known internationally in the late 1940s, played a critical role in boosting Pentecostal wave in Kenya despite being a Baptist. His mass crusades, healing sessions and open confessions of the converts in Kenya of 1960s were major turning points in the history of African Pentecostalism, as his impact saw massive conversion of Kenyans in this pietistic strand of Christianity. Graham is widely viewed as one of the most influential Christian leaders of the 20th century (Gathogo 2001:82). Apart from Billy Graham, other great homileticians include Martin Luther, John Stott, John Calvin, CH Spurgeon, Billy Graham, Karl Barth, Augustine, Wakefield, Wesley and so on. Like Martin Luther, the reformer, who said that 'the pulpit was higher than the altar' (quoted in Gathogo 2001:82), Graham equally viewed the pulpit as the most important asset in our endeavour to transform humanity for the better. Some of Billy Graham's memorable quotes include

$[M] y$ home is in Heaven. I'm just traveling through this world ... Being a Christian is more than just an instantaneous conversion-it is a daily process whereby you grow to be more and more like Christ ... I've read the last page of the Bible. It's all going to turn out all right ... I have preached too much and studied too little. (Quoted in Gathogo 2001:84)

Although he was not a Pentecostal leader, Graham inspired African Pentecostalism in Kenya since the 1960s.
Besides the 1960s and 1970s' Pentecostal explosion in Kenya, which reached its climax in 1980s, the nine protestant missionary societies that were operating in the colonial (1887-1963) and post-colonial Kenya (1963-2021), like modern African Pentecostalism, attempted to display some elements of evangelical Christianity. Although Billy Graham (an American Baptist) and TL Osborn were not necessarily the founders of Pentecostalism in Kenya, their elaborate activities, especially the healing rallies, had huge impacts that largely overshadowed the previous ones, and eventually fuelled African Pentecostalism as we know it today. Additionally, the fact that the duo received elaborate press coverage, hitherto unknown in Kenya's Pentecostal historiography was an added advantage in this endeavour.

As early as 1895, the American-leaning African Inland Mission (AIM), which began under the leadership of Peter Cameron Scott, had demonstrated evangelical traits from the outset. It was renamed African Inland Church (AIC) on 16 October 1971, after the African adherents insisted on the change of name for the religious outfit. In other words, the AIM formally transferred its authority and property to the Africa Inland Church (AIC) in Kenya on 16 October 1971, after which the editor of Inland Africa Journal, in New York, wrote a sensational feature article: 'The Day Our Mission Died' (Gathogo 2001:18). Considering that AIM was renamed AIC in 1971 after what I would refer to as the 'racial conflict' between European missionaries and the leading African converts, we may need to appreciate that it was simply Gospel versus culture conflict and/or Western versus African cultural conflict. Nevertheless, the seed of African Pentecostalism in Kenya had been planted in as early as 1895 .

Critically important is the fact that amongst the nine missionary societies that attended the infamous Kikuyu Ecumenical Conference of 1913, it was the AIM who displayed a unique and passionate agenda of 'converting' others into a more vibrant version of Christianity that practised baptism via immersion. They took conversion, testimonial admissions of one's sinful nature and the forgiveness of sins through Christ, and open confession of Christian faith as critical aspects of Christian mission amongst other pietistic strands. At one stage, their delegates were insisting on the need for re-baptising the AngloCatholics who would get into their churches, within their spheres of influence (Gathogo 2020b). They would view Anglicans (Church Missionary Society [CMS]) as not Christian enough and/or not evangelical enough. African Inland Mission's zeal in evangelism is in continuum with the modern African-Pentecostal wave, save for their ethnocentric posture, a phenomenon where they had no room for dialogue with Africa's indigenous and ritualistic realities. Certainly, this was the overall posture and/or characteristic for all the nine European protestant missionary societies of the 19th- and 20th-century Kenya. Curiously, they viewed the African God as a deus otiosus (idol god) or deus remotus 
(a withdrawn god), and the general religiosity as animistic (Parrinder 1962:21).

Besides the AIM's African-Pentecostalism traits, Kenya witnessed the arrival of a Pentecostal missionary team from Finland in 1912. To this end, Joshua (2019) explained that:

The earliest Pentecostal missionary to arrive in Kenya was a Finnish seaman, Emil Danielsson, in 1912. He stayed in Africa for 7 years and returned after the First World War. In 1918, North Americans established work at Nyang'ori, western Kenya, which was later associated with Pentecostal Assemblies of Canada (PAOC) and registered locally in 1965 as PAG [Pentecostal Assembly of God]. (p. 2)

In turn, the 1912 Finnish missionaries were part of the Missions and Developmental Aid Organisation of the Pentecostal Churches of Finland, whose roots can be traced to 1911 when the movement was founded in Helsinki, Finland. It was on 6 July 1912 when the new Pentecostals who emerged after the preaching of T.B. Barratt, the pioneer Pentecostal leader in the neighbouring Norway, held a farewell meeting in Helsinki, Finland, where Emil Danielsson (1878-1965) was subsequently sent out as a missionary to Kenya. It is precise to note that, no local Pentecostal Church ever existed in Finland at that time, and Danielsson's support, during the First World War (1914-1918), was sporadic. He wanted to establish his own mission work, but was unable to obtain the necessary permission because of financial constraints (Ahonen 1984:46). Previously, Emil Danielson (1878-1965), a seaman, had converted into Pentecostal faith after meeting some Norwegian evangelicals in Cape town, South Africa, in 1903. It is during this encounter that he accepted Christ as his personal saviour in a meeting that was held by the Norwegian missionary, C. Schong (Ahonen 2004:42). Upon his return to Finland, Emil stopped in Norway where he became a co-worker with T.B. Barratt; he also served as his interpreter when he (Barratt) came to minister in Finland. Characteristically, Finland's new believers (Pentecostals) were enthusiastic about mission work. Coming to Kenya in 1912, Danielsson pioneered Finnish Pentecostalism under the auspices of Finland Free Foreign Mission (FFFM).

As the FFFM sought to build a national Church, independent of foreign influence, it was logical and expedient that the foreign name be done away with, and the local national name be adopted. It was Lauri Pesu's suggestion that the name be changed to the Full Gospel Churches of Kenya (FGCK) (Njogu 2021:106). The suggestion was met with unanimity; and John Richard Langston Rumsey, the Assistant Registrar of societies, certified that the FGCK were exempted from registration under section 5(2) of the societies ordinance of 1952. He then signed the certificate of exemption from the registration (No. 1151 in the Kenya Gazette). In a nutshell, the FGCK Church, started by the FFFM as a Pentecostal missionary society, graduated into a registered church in 1949 and went on to earn exemptions as a religious institution in 1950s and beyond, and has continued as an African-Pentecostal outfit, to date. To this end, the newly appointed trustees' names were sent to the Principal Registrar of Documents in the capital city of Nairobi, on 21 March 1964. This was however done with the help of the FFFM office in Helsinki, Finland. These pioneer trustees were as follows: Lauri Pesu, Anna Lisa Antturi, Hezekiah Kiptoo Koech and Francis Atemo (Njogu 2021:108). Whilst the latter two were Kenyan Africans, the other pair remained Finnish missionaries in the post-independent Kenya (1963 onwards). By May 2021, FGCK (2021) had:

[E]xpanded to include all [the 47] counties [of Kenya] other than Mandera and Wajir [counties] where we have a fellowship only. The church membership [was] estimated at slightly over a million members' country wide. (p. 1)

The change of name was a momentous occasion for the missionaries, especially Mauri Viksten (1920-1995), who had been eager to Africanise and nationalise the missionary work. Viksten had been a Finnish Pentecostal missionary in Africa for 30 years. Hence, his wish to see an Africanised Pentecostalism via FGCK was based on his long years stay in Africa (Njogu 2021:107). Despite the 1912 Finish attempts at introducing Pentecostalism in Kenya, it is worthwhile to reason out with Barrett (ed. 1973:248), who notes, in the Kenya Churches Handbook, that a group of Pentecostal adherents had existed in Western Kenya since 1910, and were located seven miles from where Emil Danielson (1878-1965) was ministering. Was Barrett referring to the discourses of the American founded mission society, the AIM, which had some elements of Evangelical-Pentecostal characteristics since 1895 when it first entered Kenya? Barrett's (ed. 1973) 'caution' to our understanding of the birth of African Pentecostalism points out to the broad nature of the subject under consideration and encourages further research studies on this area.

As a progression of Pentecostal ministry, the FFFM was fully established, in Kenya, by 1927 despite their arrival in 1912. In other words, their impact was felt more from 1927 onwards. In the 21st century, Fida (2021) International, like FFFM, was equally working hard for global missions, and as its website says:

Fida International is a Finnish faith-based organisation working in global missions, community development and humanitarian aid in 50 countries. We aim to bring hope and a better future to all nations - especially to children living in poverty. We work in close cooperation with Pentecostal churches and other nongovernmental organisations and partners. In church partnerships our mission is to share the love of Christ and mobilise churches for holistic ministry in their communities. Our community development programmes in 15 countries are funded by the Ministry for Foreign Affairs of Finland. (p. 1)

In the FGCK (2021) website, Fida International is described as a development partner that supports the 'development work of the church as detailed in the projects'. It is also explained that there are other 'organizations from USA and Australia that are working with FGCK too'. Indeed, this is a pointer to the Euro-American links to the African Pentecostalism in Kenya today. 
Like other Pentecostal outfits, the goal of FFFM was to promote the Great Commission (Mt 28:18-20), thereby reaching out to the whole world through evangelisation, church planting and conversion of the diverse peoples of the world with great urgency. Apart from the coming of the Finnish Pentecostal team in Kenya in 1912, the year saw the arrival of the charismatic movement called Roho (meaning Spirit), which emerged in the Anglican Church. As noted earlier, this was followed, in 1918, by the establishment of the Pentecostal Assemblies of Canada, which affiliated itself with North Americans. It later graduated into Pentecostal Assemblies of God (PAG) in 1965 for affiliate churches (Anderson 2004:111-112).

As noted by Gathogo (2010), the evangelical protestant missionary societies in the colonial Kenya, who met at the Church of the Torch, Thogoto, Kiambu County, during the infamous Kikuyu Conference of 1913 were as follows:

[T] he Gospel Missionary Society (GMS), the German Lutheran Mission (GLM), the Friends Africa Mission (FAM), Seventh Day Adventists (SDA), the Church Missionary Society (CMS), the Church of Scotland Mission (CSM), the United Methodist Mission (UMM), and the African Inland Mission (AIM). (p. 78)

These protestant groups displayed evangelical Christian faith that is close to the modern African Pentecostalism, despite their western bias. Like other Evangelical outfits, African Pentecostals stresses on the importance of being 'born again', the centrality of elaborate confession, conversion and/or salvation, the authority of the Bible as God's revelation to humanity, the crossing of frontiers so as to reach out to the 'lost world', highlighting on inerrancy of the Bible and proselytising practices.

In 1930s, Pentecostal spirit was evident during the female circumcision crisis in Central Kenya, as this saw the creation of African indigenous churches, such as the African Independent Pentecostal Church of Africa (AIPCA). Equally, the East African Revival Movement (EARM) reached Kenya in 1937 via Uganda and moved the mainline protestants into evangelical-charismatic Christianity akin to African Pentecostalism (Karanja 1999:58). The 1940s and 1950s saw an increased Pentecostal activism in Kenya. In 1942, the African Israel Church Nineveh was founded as a breakaway from the Pentecostal Assemblies of Canada. In 1944, the missionaries from the United States of America started the Pentecostal Evangelical Fellowship of Africa (PEFA), as the FGCK was officially registered by the Finnish missionaries in 1949. The general history of the FGCK can be retraced from an account that was written by Anneli Jerkku, 'A History of the Finnish Free Foreign Mission in Kenya (1949-1998'. In this publication, she addresses the FGCK in four sections: (1) its preparation period (1912-1948), (2) pioneer period (19491962), (3) development period (1963-1979) and (4) its consolidation period (1980-1998) (Gikungu 2007:2).

Furthermore, the coming of an American Evangelist, T.L. Osborn, in Kenya, in 1957, saw an explosional healing ministry in Mombasa in the coastal region of Kenya. Osborn was uniquely able to confront witchcraft and other cuttingedge issues in concrete ways, and was able to draw huge enthusiastic crowds (Anderson 2004:112-113). Following the declaration of Kenya's independence in 1963, more foreign Pentecostal missionaries arrived in Kenya, and this went simultaneously with the birth of more Pentecostal-leaning African Indigenous Churches. To this end, Joshua (2019) noted that:

In 1967, an American Pentecostal preacher, Dale Brown, founded the Kenya Assemblies of God (KAG), which a survey in the early 1990s [was] credited as Nairobi's fastest growing denomination with an annual growth rate of 38\%. In 1970, Joe Kayo founded the Deliverance Church of Kenya, which attracted urban youth and by '1976 was an important member of the Evangelical Fellowship of Kenya (EFK)'. Between 1972 and 1986, the number of Pentecostal churches in the country doubled as its urban presence became increasingly characterised by Televangelism, prosperity theology and crusades by Western preachers. In 2003, Kenya's population was approximately $63 \%$ Protestants and 26\% Catholics (CBS, MOH \& ORC Macro 2003). The 2006 Pentecostal Forums' Survey indicated that renewalists including Charismatics and Pentecostals - accounted for more than half of Kenya's population. (p. 3)

Thus, after 1963, when Kenya attained her political independence, more foreign Pentecostal missionaries found their way into Kenya. In particular, '[t]he Norwegians came earlier in 1955, whereas their Scandinavian counterparts arrived in 1960' (Joshua 2019:1). It is no wonder that the erstwhile Kenyan Attorney General, Amos Wako, confirmed in 2007 that his office had already gotten overwhelmed by the increasing demands for registration by AfricanPentecostal Churches. By 2007, the Kenya government was processing 6740 applications. By 2010, there were over 10000 registered African-Pentecostal Churches in Kenya (Gathogo 2011a:134). It is no wonder that by 2021, an estimate of $30 \%$ -35\% of Kenya's population ( 54857497 by 04 June 2021 based on Worldometer elaboration of the latest United Nations data) were African Pentecostals. This means that Kenya is one of the most Pentecostal countries in Africa and globally. Furthermore, whilst the mainline churches in Kenya were traditionally seen as synonymous to the former European missionary societies that evolved into churches (refer to the Roman Catholic Church, the Anglican Church, the Methodist Church, the Presbyterian Church, the AIC and the Presbyterian Church of Eastern Africa), new demographics in the 21st century have demonstrated that the FGCK, whose membership has shot up to over one million adherents, has also been classed in the same category. Similarly, the Baptist Church, with a membership of about 800000 members, has also joined this league of mainstream churches in the 21st century (Gathogo 2011b:99-107; McKinnon 2020:42). The Baptist Church and the Full Gospel Church of Kenya have eclipsed some of the so-called missionary churches, at least when we consider the size of their membership. This is evidently clear when we sample the Seventh Day Adventist Church, which attended the Kikuyu Conference of 1913 that brought the European missionary societies together, as her membership stood at 530341 by May 2021 (Gathogo 2011b:99-107; McKinnon 2020:43). Equally, the British ecclesiastical outfit, 
the Methodist Church, which entered Ribe, in the Kenyan coast in 1862, stood at 450000 adherents by May 2021; yet FGCK and the Baptists had about a million adherents each. Although the Anglican church of Kenya, which entered Kenya in 1844, and the Presbyterian Church of Kenya, which entered Kenya in 1891, had 5 million and 4 million adherents, respectively (Gathogo 2011b:99-107; McKinnon 2020:44), being seen as in close figures with some African-Pentecostal churches such as the FGCK is a clear indication that the latter are the fastest growing churches in Kenya and the tropical Africa. Such shifting and soaring figures show the growing influence of African Pentecostalism in the Kenyan and the African context.

\section{The shifting landscape}

Wariboko (2017:7) pontificated that the shifting landscape of African Pentecostalism, a phenomenon where their theologies and practices have changed in the 21st century, will reshape the future direction of normative Christianity in the tropical Africa. In other words, the mainline churches are already feeling the weight of African Pentecostalism as their exuberant and 'energetic' theologies, spiced with African diets of communality, are reverberating across the African landmass, and the rapid tempo cannot be slowed down. Wariboko (2017) view the future as wide open and pregnant with possibilities of a new movement that will go beyond African Pentecostalism itself. He says:

\footnotetext{
... prayer for African Pentecostals is not your grandfather's fare. It is highly engaged and involves a stupendous amount of energy. The Pentecostal aesthetic of prayer is an irruption of sensibilities, sensory-motor skills, practical wisdom, and deep emotions for conveying everyday needs to the heavens and bridging the gap between the visible and invisible realms. Prayer is oral theology, biblical texts, ritual practices, and spontaneous and heady spirituality carried by and articulated through the body. Prayer - the embodiment, display, and articulation of ideas, hopes, fears, habits, and traditions - is a key feature of African Pentecostalism. (p. 8)
}

In the Nigerian context, Wariboko (2017:8) views the AfricanPentecostal movement as a 'very evangelical in orientation, seeking to convert both Muslims and adherents of traditional religions to Christianity'. This proselytising and evangelical aspects have been noted as similar to the one in the Kenyan context.

Igboin (2020:7) asserted that although the so-called classical Pentecostalism revolved around Holy Ghost baptism, personal salvation, exorcism, healing services and dispensationalism, African-Pentecostalism and neoPentecostalism have surpassed these theological streams. As he further argues, this does not rule out the fact that the origins of Pentecostalism, in general, was largely associated with politically, economically, exploited lot, socially deprived people who were ironically in the world, even though they were in reality cut off from it. In other words, Pentecostalism, like in the rest of Christendom, initially attracted the lowly in the society. With time, it widened its perspective and in the 21st century, it focuses on socio-economic matters worldwide (Ishaya 2011:149). Comaroff (2015) explained this shift thus:

There has also been a widespread popular impetus, in the early 21st Century world, toward redefining the role of religion in the civic order; a widespread effort to recover a sense of authenticity and sovereign authority in the world. All this implies thoroughgoing structural transformation. Indeed, there is much to suggest that the character of contemporary faith is integral to a reorganization of core components of capitalist modernity as a social formation, a world-wide process that has specific implications for postcolonial Africa. This shift has involved an intensification of some signature features of modern society, and an eclipse of others, a process made manifest in the changing ethos and institutional form of liberal democracies across the world. These changes vary in local manifestation, and so, too, does the nature and impact of religious revitalization. (p. 232)

Similarly, Kalu (2018) pointed out that the 'big men' syndrome emerged after independence and conceived independence as an end in itself as opposed to being a means to an end. This graduated into the emergency of some cultic personalities amongst some African Pentecostals. Coupled with this, the prosperity dimension has also become part of the new package. This also goes hand-in-hand with teachings that emphasise on security against spiritual and physical forces (Walton 2012).

According to Gathogo (2020a:391-409), the shifting landscapes are not without pains and some limited inconveniences; for pockets of infidelity are also experienced amongst African Pentecostals in the 21st century. In building on many samples in post-colonial Kenya, according to Gathogo (2020a):

[T]he Moral Question among African-Pentecostals has always manifested itself through marital infidelity, spouse-swapping, poor leadership structures, con artistry, financial exploitation of the poor, faking miracles, and skewed populist sermons, among others. (p. 391)

The shifting landscape, in the 21st century Africa, thus, is not without serious setbacks, and sometimes takes on risky trajectories. Furthermore, despite pockets of moral decadence, associated with some of its leadership, which would ordinarily hurt African Pentecostalism, more and more people flock in them. Could this be out of the desire to quench the metaphysical powers that are believed to influence the existential and physical space, as in African religion? Has religion in Africa turned to be the quencher of existential spaces? With Mbiti (1969) attempting to underline the African worldview as a religious drama, and indeed, the indispensability of religion in social-spiritual discourses, the power of African Pentecostalism will continue to reverberate across the continent.

In Kenya, the shifting landscape in African Pentecostalism became clear in the 1990s during the economic depression that hit the country. During this depressive moment, the likes of the then Pastor (later Bishop) Pius Muiru and Pastor Margaret Wanjiru (later Honourable Bishop, former Member 
of Parliament, 2007-2012) and others preached their televised messages of hope, amidst hopelessness that obtained. As they propounded their televised messages of hope, little did we know that through their contextual sermons, they were winning the nation in their new trajectories. Not long, the coming of the 21st century found them ripe enough for socio-political influences in the country. During the 2005 national referendum for constitutional changes in Kenya, some leading African-Pentecostal leaders were overt in opposing the new proposed law, where the government lost, 43 versus 57 (Gathogo 2011b:99-107). From a participant observer, it was crystal clear that some African-Pentecostal leaders could be seen in political rallies, as they teamed up with opposition leaders to oppose the proposed constitutional changes. They strongly sought to justify their opposition to the legal changes by appealing to socio-cultural and theological reasons. Their new trend shows the shift from the rigid evangelicalism to a broad-based and/or liberal theological positions, akin to the emphasis on realised eschatology (present concerns) in the African heritage. It is no wonder that some went on to contest political seats from the Civic level to the presidency, although with minimal victories (Gathogo 2011b:99-107, 2020c).

Seeing African Pentecostals addressing thematic issues, such as sickness and the way of God, poverty eradication as the agenda for all, God and a healed society, exorcisms and societal healing, and God and prosperity for everyone, was, indeed, a turning point as the 21st century came closer. Furthermore, their thematic concerns, such as a hopeful nation as a Godly nation, gender issues as human issues and the rejuvenated national economy as the kingdom nation, at the turn of the 21st century, was refreshing moments that clearly showed the changing landscapes in Kenya's AfricanPentecostalism. In both the open-air spaces and in the media, the gospel of hope and healing became apparent since the late 1990s (Gathogo 2013). Furthermore, after President Daniel arap Moi left the political scene as the president of Kenya on 30 December 2002, the political role of African Pentecostals increased. The Mwai Kibaki era (2003-2013) saw the introduction of Constituency Development Fund (CDF) that begun the devolution of funds to the rural areas. In these CDF kitties, each of the 210 parliamentary constituencies were allocated funds, and hardly one could see a constituency, especially in Central Kenya, without an African-Pentecostal nominee in these CDF committees (Gathogo 2013:203-230). In one of the 47 devolved governments established in Kenya after the promulgation of the 2010 constitution, one of the African-Pentecostal leaders became the Governor (Rev. Moses Akaranga, 2013-2017, Vihiga County), whilst another leading African-Pentecostal Pastor became a cabinet minister (Rev. Moses Dzoro, Kaloleni Constituency - 2002-2007) during Mwai Kibaki's first term, 2003-2013 (Gathogo 2015a:97). Having eschewed politics, which the openly dismissed as secular and ungodly, prior to the 21st century, the socio-political landscape had clearly showed a more vibrant holistic movement in their new socioreligious discourses.
The socio-political influence of African Pentecostalism in Kenya has remained in the 21st century, and it appears that this rapid tempo will not slow down. Certainly, this shift from conservative evangelicals to an all-rounded religious movement is 'cooking well from the nethermost depths of the Ocean floor, rather than from the top stratums' (Gathogo 2020b:1) - as the lowest level of society seems to have embraced it. This view was further boosted on 07 January 2021 when the United Democratic Alliance (UDA) party unveiled the ecclesiastical leader of a leading AfricanPentecostal outfit, the JIAM, Bishop Margaret Wanjiru Kariuki, as their Gubernatorial candidate of the capital city of Nairobi. The vacancy for a Governor of the city of Nairobi was created after the Senators voted in a 27-16 to impeach the flamboyant Governor Mike Sonko on 17 December 2021 (Cheruiyot 2021:1). Although the elections did not take place because of some legal-technical reasons, the nomination of the former Deputy Minister for Housing and Member of Parliament for Starehe Constituency (2007-2012) by the influential UDA further confirmed the shifting landscape of Kenya's African-Pentecostalism, a phenomenon where their social influence is now explicit (Cheruiyot 2021:1). The shift from less influential to a very influential religious AfricanPentecostal outfit can be seen from two prongs. Firstly, the public is no longer complaining that some African-Pentecostal leaders are abandoning the sheep and indulging in elective politics, as in the above Gubernatorial case. Hence, a level of acceptance is visible amongst the general public. Secondly, both the mainline Churches and African Pentecostals are not overtly condemning this indulgence of 'secular' politics amongst African-Pentecostal leaders, or any other Church leader for that matter. Clearly, the shifting landscape is visible in the 21st century.

In the researcher's interviews with several well-informed scholars and African-Pentecostal leaders, it became clear that the shifting landscape is evident right from the village churches. First, the religious outfits which used to call themselves Ministries in the 20th century renamed themselves Churches. A case in point is the Priesthood Fellowship Church (PFC) under the former Pastor J.J. Gitahi (now Bishop Dr. J.J. Gitahi) is no longer called Priesthood Fellowship Ministries (G. Kariuki [KU-Mombasa Office] pers. comm., 14 April 2021). Furthermore, the outfit where her leaders or clerics did not wear Clerical gowns, Clerical shirts and Clerical Collar are now doing so, as in the PFC case. Furthermore, the PFC as with other African-Pentecostal outfits have embraced mainline titles for their leaderships. Such leadership titles include Bishops, Archbishops, Reverends and Archdeacons for some. Of course this depends on the individual church (G. Kariuki [KU-Mombasa Office] pers. comm., 14 April 2021). Equally, the Refined Gospel Christian Church (RGCC), which constituted its first congregation on Sunday 07 December 1997 at Kikuyu Township, Kiambu County, following its registration as an African-Pentecostal Church in Kenya, had Pastor John Wambu Waweru as its General Overseer (head). Between 2000 and 2021, the title of the church leader had shifted from 
Senior Pastor, Overseer, General Overseer, Bishop to the current position where Archbishop Dr. John Wambu Waweru is the current head by 2021. The old titles, such as Overseer, Elder, Senior Elder, Deacon and Apostle, are already giving way to the new ones, largely taken from the mainline churches.

Amongst the vestments that both the African Pentecostals and the mainline churches are wearing today include Cassock, Amice, Alb, Cincture, Stole and the Chasuble (G. Kariuki [KU-Mombasa Office] pers. comm., 14 April 2021). Whilst Chasuble is the outermost liturgical vestment worn by Clergy for the celebration of the Eucharist amongst Anglicans, Roman Catholic, and Lutheran Churches and other mainline churches, Cassock, the floor length garment, is also the long priestly garment, and is usually black, with long sleeves and fits the body closely. The latter is worn by the Clergy both as ordinary dress and as a liturgical garment. According to Benson Ngiri (B.W. Ngiri [FGCK Elder Benson Wachira Ngiri Benson] pers. comm., 14 April 2021), a section of African-Pentecostal outfits has embraced these vestments, whilst others are still sceptical. Generally, Cleric robe is the outer cassock, worn over as the inner garment by Bishops, Priests, Deacons and Monastics. It is sometimes accompanied by Skufia, which is a soft-sided cap worn by monastics or awarded to certain clergy, as a mark of honour and/or designated recognition. Equally, the outer cassock is a large flowing garment worn over the inner cassock by the clerics. Embracing these elements, for some of the African Pentecostals, points to a shifting theo-ecclesial landscape amongst the African Pentecostals.

In an interview, Ngiri (B.W. Ngiri [FGCK Elder Benson Wachira Ngiri Benson] pers. comm., 14 April 2021), a leading elder, revealed that although his specific African-Pentecostal Church, the FGCK Kagumo, had not embraced the full shifts that others were experiencing by April 2021, there were clear changes that were evident, especially within his home County of Kirinyaga. He noted that even though they still have titles for an overseer, as a Church leader who stewards districts, regions and the national levels, they are no longer used widely. At the district level, which is basically a subcounty in Kenya's administrative structures, an overseer is the Bishop. Ngiri (B.W. Ngiri [FGCK Elder Benson Wachira Ngiri Benson] pers. comm., 14 April 2021) went on to explain that Kirinyaga county has three administrative areas that serve their African-Pentecostal Church (FGCK): Kirinyaga West (Ndia and Kirinyaga Central) under Bishop Joshua Kiongo, deputised by Bishop Joseph Muriithi Karugendo by April 2021, Kirinyaga South (Mwea) under Bishop Dominic Njenga deputised by Bishop Symon Munene Nyange, and Kirinyaga East (Gichugu) under Bishop Njue, deputised by Bishop Eric Mwangi. Prior to this, the entire Kirinyaga county of Kenya was one of the districts of FGCK in 2019 and had a Senior Pastor as the Head, and stayed in their Headquarters at Kerugoya Town. In 2019, thus, the then Senior Pastor who had become the only Bishop in the entire county, Joshua Kiongo Kimani, had two more Bishops who came in and joined him to lead the three districts that were created.
Other administrative centres, akin to the structures in the mainline Churches, for the FGCK include the Mt. Kenya South region that was by April 2021 headed by a Regional Overseer (RO), and covered Kirinyaga, Nyeri, Embu and Laikipia administrative counties of Kenya. The Mount Kenya South region has a $\mathrm{RO}$ as the Head. In the 21st century, the RO carries the title of a Bishop. Although the FGCK had not embraced the leadership title of an Archbishop, by April 2021, Bishop Silvanus Nyaga, from Manyatta of Embu county, was heading the entire Mount Kenya South region. As observed by Ngiri (2021), 'nobody ever imagined that these titles will be used in FGCK and other African-Pentecostal Churches'. These shifts are largely informed by interactions and cultural diffusion (Gachoki 2021). In regard to the clerical robes, both Ngiri (2021) and Njogu (2021) noted that it is not fully adopted in the FGCK, but gradually becoming the norm. In Kirinyaga South (Mwea), Bishop Dominic Njenga wears these vestments. Equally, the immediate former General Overseer, Kathitta from Mwingi-Kitui county prefers to wear clerical robes whenever he is carrying out religious duties. He retired on medical grounds in early 2020. In Kirinyaga West, Rev. Ismail Mwai Mabiu, the pioneer and founder of FGCK in the region, and Bishops Kimani and Karugendo are not keen on using the vestments. Whilst Bishops Karugendo and Kimani are silent about these shifting sands in FGCK, Rev. Mwai, who retired in 1988, insists that FGCK should retain the status quo, as wearing clerical garments is tantamount to copying others. Billed as a pioneer and liberationist icon, Rev. Mabiu appears to contradict his mass African-Pentecostal liberation theology that he uniquely propounds as a measure of empowering the people (Njogu 2020:1). Nevertheless, this was just his postretirement projects that equally points to the shifting landscape amongst African-Pentecostal leaderships. Beyond vestments, FGCK, like other African Pentecostals, is encouraging theological education as a prerequisite for their leaderships. That is, it is no longer 'let the Holy Spirit' teach Pastors and the congregation; rather, the place of the Holy Spirit is well taken care of. The place of theological education is equally getting taken care of. As a matter of fact, 'there are Doctors in theological education in FGCK these days ...' (Ngiri 2021).

\section{The big men syndrome}

To an extent, the failure of the traditional African systems (Ubuntu), where the joy of one was seen as the joy to all and vice versa, is the reason for the emergency of African Pentecostals' involvement in elective politics and the Big Man or Big Woman syndrome that is prevalent in some of these ecclesiastical outfits (Gathogo 2008:39-53). The identity crisis that is evident after the failure of African cultural systems and its unholy alliance with the western trajectories has created a huge vacuum in the African worldview that is not yet addressed. In view of this, Kalu (2018:21) asserted that the African Big Men or Big Persons began after the political independence in 1960s, as they viewed freedom from colonialism as an end in itself rather than a means to an end. They then failed to build institutions for posterity and further failed to appreciate that Africa does not need the Strong Men or Strong Women; rather, Africa needs strong 
institutions (Gathogo 2020e:1-8, 2020f:1-7). As a result, the strong men (no women initially) built personality cults and were eventually idolised as God's sent, God's chosen and/or unique people of their own kind. They would amass instant wealth at the detriment of the increasingly poor citizenry (Gathogo 2020e:1-8, 2020f:1-7). Hence, Africa's postindependence Big Men amounts to a systematic looting through primitive accumulation of wealth, which is hard to account for, a development that ironically pushes the ordinary folk to revere them as heroes and heroines and/or messengers of God almighty.

Under such circumstances, bandit economies in the postcolonial Africa have emerged (Gathogo 2020d). Without any moral underpinnings, 'survival for the fittest' economies only make the 'stronger' ones wealthier and the 'weaker ones' become poorer; hence, African history is replete with cases of failed states, a failure that is squarely blamed on Africa's Big Men syndrome. It is a tragedy when such unfortunate scenarios are replicated in ecclesiastical outfits. In such situations, the poor are eventually blocked from legitimate means of survival, and are fatalistically forced to continue walking through the precarious valleys of the shadows of death and destruction (Psalms 23), as God remains their comforter. The increase of substance abuse, suicide cases, domestic violence, family break-ups, alcohol abuse, violence flare-ups along the ethnic lines, constant xenophobic attacks and other forms of Unyama or Ubulwane (beastly conduct) are symptoms of a volcano that is ready to erupt (Gathogo 2008:39-53, 2015b:1-9). In this understanding, the African-Pentecostal Big Men and Big Women, in the 21stcentury Kenya, is a progression of an alternative to the breakdown of the African cultural systems whose spirituality was strictly adhered to. In a community where a Muthamaki (revered elders or leaders) were ontologically seen as holding brief for Ngai (God), a vacuum cannot be entertained (Gathogo 2021:1-9). Curiously, the Big Persons' syndrome, in the 21st century, is visible in both the political and the ecclesiastical circles, and is clearly a concern in modern scholarship.

Aniche (2018:236-255) has attempted to unveil the cause of the shift of African-Pentecostal landscape and the emergency of the Big Men and Big Women in the African-Pentecostal leaderships by relating it to the national politics. As the African governments fail to address cutting-edge issues facing their respective societies, the African-Pentecostal's Big Persons emerge with a promise for a better day. In other words, the failure of the political establishments in the socioexistential realm triggers this shifting of landscapes to an extent. This means that the Church now becomes an alternative government by default, a government that compliments the failures of the central government. Does that make African Pentecostalism the light and salt of the world (Mat 5:13-17), in an environment where darkness is more than light or does it compound an already bad situation by adding insult to an existing injury? Burgess (2015:291-232) has, however, pointed out that even when African
Pentecostals participate in elective politics, they do not lose their 'Pentecostal State' and/or theological direction. This is, however, debatable as different samplings would provide divergent results. As the African societies look for alternative security and/or source of hope, it will be foolhardy to ignore these African-Pentecostal shifts in all pillars of culture (refer to economics, politics, ethics, aesthetics, kinship and religion), as even the African indigenous systems are holistic and never isolates any department of life (Mbiti 1969:1-2). The challenge of unquestionable obedience, amongst adherents, to some pockets of African-Pentecostal leaderships whose moral underpinnings raise concerns, is another question altogether.

In trying to understand the shifting landscape of African Pentecostalism in the 21st-century Kenya, it is necessary to ask the following questions: have the religious outfits that operated as mere 'temporal' ministries under Overseers, Apostles, Pastors and General Overseers amongst other titles shifted to churches with Reverends, Bishops and Archbishops as the new titles for their ecclesiastical leaderships? Has the wearing of clerical shirts and collars become the new norm? Certainly, the $180^{\circ}$ turn has not taken place, as there are pockets who have retained their conservative stances right into the 21st century; at least in some limited areas. And are the words of an anonymous person accurate in regard to African Pentecostalism, thus:

[C]hristianity began as a personal relationship with Jesus Christ. When it went to Athens, it became a philosophy. When it went to Rome, it became an organisation. When it went to Europe, it became a culture. When it went to America, it became a business [and created a Big Man/woman syndrome in post-colonial Africa]? (Anonymous person quoted in Gathogo 2011a:133)

As noted above, an interview with the leading elder in the FGCK, Kagumo, in Kirinyaga county of Kenya, Benson Wachira Ngiri (2021), revealed that pockets of AfricanPentecostal Churches have viewed the shifting landscapes with scepticism.

\section{COVID-19}

After Kenya's Minister for Health, Hon Mutahi Kagwe, announced the first confirmed case of coronavirus on 13 March 2020, prophets and their prophetic extravaganza began (Muchui 2020) to shape up as they expressed their personal and ecclesiastical idiosyncrasies. This went handin-hand with biblical insights, mainly from the AfricanPentecostal wing of the church, some of which tried to prove that COVID-19 was a biblical fulfilment. Others saw it as prophecies that had been fulfilled, as pockets of commentators-cum-pastors viewed it as a punishment for unrepentant Kenyans. The latter failed to appreciate that it was a global challenge where India, Brazil, China, Italy, France, Spain, Argentina, Turkey, Germany, Russia, Italy, United Kingdom, South Africa, Egypt, Morocco, Tunisia, Ethiopia and the United States of America were some of the most affected countries (Milani 2021:223-252). Some of the biblical messages (via WhatsApp) that have been circulated through the social media include: 
$[A]$ s the world wide quarantine proceeds of COVID-19, even from the Church, the Holy Mountain where we meet our God of mercy, it is now the moment to quarantine from every kind of sin for God to embrace us back. Let us make Church a place of worship, love one another and fear God. Let us make the world a garden of joy. Let us take a moment with our ears and ask ourselves individually, what is God feeling about us? (Jr 7:3, 8-15)

Another critical dimension is the various 'prophecies' made by various well-known African-Pentecostal leaderships in Kenya. As Parsitau (2020) says:

Self-proclaimed Prophet Owuor has trafficked in fear-mongering threats, and has even claimed that he had prophesied the pandemic. He also said it would kill people in Asia because the continent rejected his prophecy. In Kenya, a section of the public has cajoled him to unleash his 'mighty prophetic powers' to fend off the virus. They have also called on him to pray it away. (p. 1)

Parsitau (2020) wondered why there were no spiritual powers to perform miracles and heal coronavirus patients when it is so desperately needed. She went on to cite some African-Pentecostal clerics who, in her view, appeared to be too ignorant of COVID-19, and hence, they were in a confused state when the government closed down the churches. She cites the case of:

[A]postles James Maina Ng'ang'a's video on coronavirus where he is unable to pronounce the word coronavirus - showed not just his sheer ignorance, but also how ill-equipped he and his ilk are when it comes to offering solutions to such complex 21stcentury problems. (p. 1)

The ignorance amongst the African-Pentecostal leaders was further displayed by Rev. Nathan Kirimi, a Meru-Tiganiabased Pastor (Eastern Kenya), of Jesus Winner Ministry, who angered many Kenyans when he dismissed COVID-19 as a global hoax (Muchui 2020:1). He went on to say that God had instructed him not to close his church or terminate services as coronavirus is inexistence and non-issue. By 18 March 2020 when Pastor Kirimi was dismissing COVID-19 as a hoax, it had already claimed 9800 lives globally. In providing the government directive on banning social gatherings, the Minister for Health, Hon Mutahi Kagwe, invoked the Public Health Act (PHA), which gives him a broad legal authority to impose various forms of restrictions whenever a public health crisis occurs (Muchui 2020:1). As a demonstration of the shifting landscape in African Pentecostalism, a phenomenon where the use of science and technology has become the vogue, Rev. Kirimi was subsequently opposed by the higher church hierarchy publicly. In this unprecedented move, Bishop Mwai, his senior, noted that the:

[M]anagement, Board and the Secretary of Jesus Winner Ministry wish to inform Kenyans that the statements made by Rev Nathan Kirimi of Meru are his personal opinions and do not reflect the official position of the church. The board has already instituted remedies and summoned the pastor to ensure that such an occurrence won't be repeated now or in the future. (Muchui 2020:1)
Certainly, such denunciation of some of their wayward members, who over spiritualise critical matters, was a major turning point in Kenya's historiography.

\section{Conclusion}

The biggest challenge for African Pentecostalism in the 21st-century Kenya and the tropical Africa is the COVID-19, which entered the country on 13 March 2020. The existence of pandemic was publicly announced by the Health Minister Hon Mutahi Kagwe and confirmed after three consecutive tests. During that time, some Kenyan prophets, mainly from the African-Pentecostal wing of the Church, reacted in diverse ways. Some accepted the government's position of closing down churches, which were seen as breeding grounds and/or seedbed, whilst others downplayed its existence, as 'it was simply for punishing a few sinners before it evaporated into the thin air'. Some prophesied a huge punishment to the government for disrespecting churches via closures and/or lockdowns. The most intriguing bit in these discourses is the sizeable percentage that was ready to walk with the government's stand, and their appreciation of science as equally God's way in guiding human survival. The latter demonstrates the changing landscape in African-Pentecostal theologies, as one would have expected a total uniform statement of opposition to lockdowns, at least when judging it from the 20th-century experiences. Were the African Pentecostals and the Church, in general, silenced by the pandemic, and did the State play its role appropriately in addressing the pandemic? Certainly, the general support offered by a large majority of the African Pentecostals in Kenya was a huge demonstration of the shifting landscape amongst the erstwhile conservative and rigid religious outfits.

This research study, which set out to demonstrate the shifting landscape in African-Pentecostalism, has ably surveyed the history of African Pentecostalism in Kenya whose spirit, it has established, was planted in as early as 1895 when the AIM, later AIC, began in Kenya. With their strong evangelical leaning, which, unlike other protestant missionary groups, emphasised on baptism by immersion, deep meditation, and had strong evangelistic zeal, akin to African Pentecostals, AIM turned to be the de-facto Pentecostals in Kenya before Pentecostalism. This is compared with Justin Martyr's (100-165) remark that 'Socrates was a Christian before Christ' (Gathogo 2020b:8). In other words, the study has demonstrated the possibility of Pentecostalism amongst the AIM even before the 20thcentury Pentecostal explosion globally. The study has also demonstrated the shifting landscapes by addressing their new emphasis on theological training, their use of cassock, collar and the clerical shirts; the use of titles that are common in the mainline or mainstream Churches, such as Reverend, Bishops, Archbishops and Deacons, that are replacing Apostle, Overseer, Elder, General Overseer and so on. Isn't this the new conscious or unconscious strategy of eclipsing the mainline or mainstream churches completely? With the membership of FGCK going well above one million in the 
21st century, and surpassing some mainstream churches, the rapid growth of African Pentecostalism in Kenya now shows that the latter's influence in the social domain is equally growing faster. Critical concerns, however, remain, and this includes the inability to dismantle the Big Man or the Big Person's syndrome in a society that claims to be democratising. For an evangelical-ecclesiastical society that unquestionably obeys the 'Big Person' even when some wayward members lead them a stray, the need to revisit the moral question remains critical.

\section{Acknowledgements \\ Competing interests}

The author declares that he has no financial or personal relationships that may have inappropriately influenced him in writing this research article.

\section{Author's contributions}

J.M.G. is the sole author of this article.

\section{Ethical considerations}

This article followed all ethical standards for research without direct contact with any human or animal subjects.

\section{Funding information}

The research output from the Research Institute of Religion and Theology (UNISA) made it possible for the author to research and complete this article for publication.

\section{Data availability}

The author confirms that the data supporting the findings of this study are available within the article.

\section{Disclaimer}

The views and opinions expressed in this article are those of the author and not necessarily reflect the official policy or position of any affiliated agency of the author.

\section{References}

Ahonen, L., 1984, Mission growth: A case study on Finish Free Foreign Mission, William Carey Library, Pasadena, CA

Ahonen, T., 2004, 'Antedating missional church: David Bosch's views on the missionary nature of the church and on the missionary structure of the congregation' Swedish Missiological Themes 92(4), 39-46.

Anderson, A., 2004, An introduction to Pentecostalism: Global charismatic Christianity, Cambridge University Press, Cambridge.

Aniche, E.T., 2018, 'Africa's big men in the continent's democratic experiments', in K. Kalu, O. Yakob-Haliso \& T. Falola (eds.), Africa's big men: Predatory state-society relations in Africa, pp. 236-255, Routledge, London.

Barrett, D. (eds.), 1973, Kenya churches handbook: The development of Kenyan Christianity, 1498-1973, Evangel, Kisumu.

Burges, R., 2015, 'Pentecostals and politics in Nigeria and Zambia', in M. Lindhard (ed.), Pentecostalism in Africa: Presence and impact of pneumatic Christianity in postcolonial societies, pp. 291-321, Brill, Leiden.

Cheruiyot, K., 2021, 'UDA unveils Bishop Wanjiru as its flag bearer for Nairobi byelection', The Star, 08 January 2021, viewed 08 January 2021, from https://www. the-star.co.ke/news/2021-01-08-uda-unveils-bishop-wanjiru-as-its-flag-bearerfor-nairobi-by-election/.
Comaroff, J., 2015, 'Pentecostalism, post-secularism, and the politics of affect in Africa and beyond', in M. Lindhardt (ed.), Pentecostalism in Africa: Presence and impact of pneumatic Christianity in postcolonial societies, pp. 220-247, Brill, Leiden.

Full Gospel Churches of Kenya (FGCK), 2021, Full gospel churches of Kenya, viewed 09 May 2021, from https://fgck.or.ke/about-us.html.

Fida, 2021, About us, viewed 02 May 2021, from https://www.fida.info/en/about-us/. Gachoki, J., 2021, Interview with John Mararo Gachoki, Kagumo Town, 15 April.

Gathogo, J., 2008, 'African philosophy as expressed in the concepts of hospitality and Ubuntu', Journal of Theology for Southern Africa 130(1), 39-53.

Gathogo, J., 2010, 'The early attempts at ecumenical co-operation in East Africa: The case of Kikuyu conference of 1913', Studia Historiae Ecclesiasticae 36(2), 73-93.

Gathogo, J., 2011a, 'The challenge of money and wealth in some East African Pentecostal Churches', Studia Historiae Ecclesiasticae 37(2), 133-151.

Gathogo, J., 2011b, Mutira mission: An African church comes of age, Zapf, Limuru.

Gathogo, J., 2013, 'African-Pentecostalism and the Kenyan political landscape', Swedish Missiological Themes (SMT) 2(1), 203-230.

Gathogo, J., 2014, 'Theo-political dominance of African-Pentecostalism in the 21st century: Lessons from the Kenyan socio-ecclesial experience', US-China Law Review 11(11), 1499-1515.

Gathogo, J., 2015a, 'Ecclesiastical and political leaderships in one armpit: Reconstructing the memory of Thomas Kalume', Studia Historiae Ecclesiasticae 41(3), 92-110. https://doi.org/10.25159/2412-4265/451

Gathogo, J., 2015b, 'Men battering as the new form of domestic violence? A pastoral care perspective from the Kenyan context', HTS Teologiese Studies/Theological Studies 71(3), 1-9. https://doi.org/10.4102/hts.v71i3.2795

Gathogo, J., 2017, 'The continuity of indigenous rituals in African Ecclesiology: A Kenyan experience from a historical perspective', Stellenbosch Theological Journal/ Teologiese Joernaal 3(1), 115-137. https://doi.org/10.17570/stj.2017.v3n1.a06

Gathogo, J., 2020a, 'Infidelity among African-Pentecostals: The Kenyan case', in C.J. Kaunda \& S.F. John (eds.), Genders, sexualities, and spiritualities in African Pentecostalism, pp. 391-409, Palgrave Macmillan, Cham.

Gathogo, J., 2020b, 'Ecclesia Anglicana Conference of September 2020: Cooking Anglican ecclesiology in a Kenyan Pot?', Jumuga Journal of Education, Oral Studies, and Human Sciences (JJEOSHS) 3(1), 1-17. https://doi.org/10.35544/jjeoshs.v3i2.30

Gathogo, J., 2020c, Contemporary theologies: An African perspective, Kairos, Nairobi.

Gathogo, J., 2020d, 'Consolidating democracy in colonial Kenya (1920-63): Challenges and prospects', Jumuga Journal of Education, Oral Studies, and Human Sciences (JJEOSHS) 3(1), 1-18. https://doi.org/10.35544/jjeoshs.v1i1.20

Gathogo, J., 2020e, 'Karubiu wa Munyi and the making of Modern Kirinyaga, Kenya', HTS Teologiese Studies/Theological Studies 76(4), 1-8. https://doi.org/10.4102/ hts.v76i4.6198

Gathogo, J., 2020f, 'A brave one legged general: The story of Mau-Mau General Kassam Gichimu Njogu', HTS Teologiese Studies/Theological Studies 76(4), 1-7. https://doi.org/10.4102/hts.v76i4.6155

Gathogo, J., 2021, 'Njega wa Gioko and the European Missionaries in the Colonial Kenya: A theo-historical recollection and reflection', HTS Teologiese Studies/ Theological Studies 77(2), a6790. https://doi.org/10.4102/hts.v77i2.6790

Gathogo, J. \& Nthukah, M., 2019, A Fallow Goldmine: One hundred years of Mbeere Mission in Kenya (1919-2019), Kairos, Nairobi.

Gathogo, J.M., 2001, The truth about African hospitality: Is there hope for Africa? Salt, Mombasa.

Gikungu, D.M., 2007, 'Dynamism in church governance with special reference to leadership conflict in the full gospel churches of Kenya', Unpublished MA thesis.

Igboin, B.O., 2020, 'Nigerian Pentecostalism, alternative state, and the question of accountability', Studia Historiae Ecclesiasticae 46(3), 1-24. https://doi. org/10.25159/2412-4265/7886

Ishaya, E.R., 2011, 'A historical analysis of the emergence of newer Pentecostal churches in Adamawa State, Nigeria, from 1975 to 2008', PhD thesis, University of KwaZulu-Natal.

Joshua, S.M., 2019, 'The Norwegian Pentecostal Mission's work in Kenya between 1955 and 1984: A historical perspective', HTS Teologiese Studies/Theological Studies 75(1), a5275. https://doi.org/10.4102/hts.v75i1.5275

Kalu, K., 2018, 'The Postcolonial African state and its citizens', in K. Kalu, O. YakobHaliso \& T. Falola (eds.), Africa's big men: Predatory state-society relations in Africa, pp. 236-255, Routledge, London.

Kalu, O., 2008, African Pentecostalism: An introduction, Oxford University Press, Oxford.

Karanja, J.K., 1999, Founding an African faith: Kikuyu Anglican Christianity, 1900-1945, Uzima, Nairobi.

Kaunda, C.J. \& John, S.F., 2020, 'Introduction: African Pentecostalism, genders, sexualities and spirituality', in C.J. Kaunda \& S.F. John (eds.), Genders, sexualities, and spiritualities in African Pentecostalism, pp. 1-16, Palgrave Macmillan, Cham.

Kibicho, S.G., 2006, God and Revelation, Acton, Nairobi.

Mbiti, J.S., 1969, African religions and philosophy, EAEP, Nairobi.

McKinnon, A., 2020, 'Demography of Anglicans in sub-Saharan Africa: Estimating the population of Anglicans in Kenya, Nigeria, South Africa, Tanzania and Uganda', Journal of Anglican Studies 18(1), 42-60. https://doi.org/10.1017/S1740355320000170

Milani, F., 2021, 'COVID-19 outbreak, social response, and early economic effects: A global VAR analysis of cross-country interdependencies', Journal of Population Economics 34(1), 223-252. https://doi.org/10.1007/s00148-020-00792-4 
Muchui, D., 2020a, 'Exposed: The Meru pastor courting coronavirus', Daily Nation, 19 March 2020, viewed 24 April 2020, from https://www.nation.co.ke/counties/ meru/The-pastor-courting-Coronavirus/1183302-5496676-g8qrdc/index.html.

Njogu, G., 2020, 'A Liberationist icon or a conservative leader? Retrieving Ismae Mwai's African-Pentecostalism and ecclesiastical leadership in Kenya', Studia Historiae Ecclesiasticae: Journal of Church History (South Africa) 46(2), 1-13. https://doi.org/10.25159/2412-4265/7604

Njogu, G., 2021, Interview with Geoffrey Njogu, Kagumo Town, 14 April.

Parrinder, G., 1962, African traditional religion, Sheldon Press, London.
Parsitau, D., 2020, 'Religion in the age of coronavirus', The Elephant-Speaking the Truth, viewed 25 April 2020, from https://www.theelephant.info/features/2020/03/23/ religion-in-the-age-of-coronavirus/.

Walton, J.L., 2012, 'Stop worrying and start sowing: A phenomenological account of the ethics of divine investment', in K. Attanasi \& A. Yong (eds.), Pentecostalism and prosperity: The socio-economics of the global charismatic movement, pp. 107-130, Palgrave MacMillan, New York, NY.

Wariboko, N., 2017, 'Pentecostalism in Africa', in Oxford Research Encyclopedia of African History, viewed 02 May 2021, from https://oxfordre.com/africanhistory/ view/10.1093/acrefore/9780190277734.001.0001/acrefore-9780190277734-e-120. 